\title{
Wawasan Nusantara
}

Whindy Salsa Nabila

IIK STRADA INDONESIA

whindysalsanabila@gmail.com

\begin{abstract}
Abstrak
Wawasan nusantara adalah cara pandang terhadap suatu kondisi bangsa. Aspek yang terdapat pada wawasan nusantara yaitu fisik atau wilayah dan sosial. Fisik atau wilayah Indonesia terdiri dari sejumlah pulau sehingga sering disebut wilayah kepulauan dan berdampak pada prilaku seseorang. Sedangkan sosial yaitu bergantuk pada aspek politik, ekonomi, sosial, budaya dan Hankam yang sedang berlangsung saat ini. Dari kelima aspek tersebut yang paling berkuasa saat ini adalah ekonomi, karena ekonomi makro dapat mengendalikan politik dan hukum. Pada mulanya kehidupan Negara ditentukan oleh Hukum lalu di bawahi dengan Ekonomi san Politik. Ekonomi dan politik berada sejajar karena Hukum seharusnya tidak bisa dikendalikan oleh ekonomi maupun politik. Ekonomi, politik dan Hukum, ketiga aspek tersebut tidak sembarangan dijadikan aspek tetapi mempunyai makna contoh Hukum yaitu mengatur Negara menjadi tertib, Ekonomi yaitu berkaitan dengan tujuan Negara atau kesejahteraan, sedangkan Politik yaitu berkaitan dengan kekuasaan. Negara lain bisa maju karena telah menerapkan dan melaksanakan aspek ini dengan baik.
\end{abstract}

\section{Kata Kunci : Wawasan nusantara}

\section{A. Latar Belakang}

Mengenai definisi Wawasan Nusantara, berdasarkan Ketetapan MPR Tahun 1993 dan 1998 tentang GBHN, Wawasan Nusantara yang merupakan wawasan nasional yang bersumber pada Pancasila dan berdasarkan UUD 1945 adalah cara pandang dan sikap bangsa Indonesia mengenai diri dan lingkungannya dengan mengutamakan persatuan dan kesatuan bangsa serta kesatuan wilayah dalam menyelengarakan kehidupan berbangsa, dan bernegara untuk mencapai tujuan nasional. Sebenarnya wawasan kebangsaan Indonesia sudah dicetuskan oleh seluruh pemuda Indonesia dalam suatu tekad pada tahun 1928 yang dikenal dengan sebutan sumpah pemuda yang intinya bertekad untuk bersatu dan merdeka dalam wadah sebuah Negara Kesatuan Republik Indonesia. Seharusnya untuk menghadapi keadaan negara yang serba sulit 
sekarang ini bangsa Indonesia bangkit bersatu mengatasi masalah bangsa secara bersamasama. Dalam penerapan Wawasan Nusantara harus tercermin pada pola dan tindak yang senantiasa mendahulukan kepentingan bangsa dan negara dari pada kepentingan pribadi atau kelompok. Dengan kata lain, Wawasan Nusantara menjadi pola yang mendasari cara berpikir, bersikap dan bertindak dalam rangka menghadapi berbagai masalah yang menyangkut kehidupan berbangsa dan bernegara. Penerapan Wawasan Nusantara selalu berorientasi pada kepentingan rakyat dan wilayah tanah air secara utuh dan menyeluruh. Penerapan Wawasan Nusantara sangat membutuhkan kesadaran warga negara dalam berbangsa dan bernegara, karena dengan kesadaran dan penguatan warga negara dalam berbangsa dan bernegara maka tujuan dan penerapan Wawasan Nusantara akan terwujud. Dengan kata lain, penguatan kesadaran berbangsa dan bernegara akan membantu dan mempermudah dalam penerapan dan tujuan dari Wawasan Nusantara.

\section{B. Kasus/Masalah}

- Bagaimana wawasan nusantara (Wanus) sebagai Konsep Persatuan Bangsa :
A. Perwujudan Wanus sebagai Satu Kesatuan Politik
B. Perwujudan Wanus sebagai Satu Kesatuan Ekonomi
C. Perwujudan Wanus sebagai Satu Kesatuan Sosial Budaya
D. Perwujudan Wanus sebagai Satu Kesatuan Pertahanan Keamanan
E. Wanus sebagai Penjabaran Pancasila
F. Wanus sebagai Wawasan Nasional

- Bagaimana Ajaran Dasar Wawasan Nusantara

- Uraikan Dasar Hukum Wawasan Nusantara

- Apa Tujuan Dari Wawasan Nusantara

\section{Tinjauan Pustaka}

Wawasan Nusantara adalah cara pandang suatu bangsa tentang diri dan lingkungannya yang dijabarkan dari dasar falsafah dan sejarah bangsa itu sesuai dengan posisi dan kondisi geografi negaranya untuk mencapai tujuan atau cita-cita nasionalnya. Ada beberapa pengertian wawasan nusantara, diantaranya sebagai berikut :

1) Pengertian Wawasan Nusantara berdasarkan Ketetapan MPR Tahun 1993 dan 1998 tentang GBHN adalah sebagai berikut : 
Wawasan Nusantara yang merupakan wawasan nasional yang bersumber pada Pancasila dan berdasarkan UUD 1945 adalah cara pandang dan sikap bangsa Indonesia mengenai diri dan lingkungannya dengan mengutamakan persatuan dan kesatuan bangsa serta kesatuan wilayah dalam menyelenggarakan kehidupan bermasyarakat, berbangsa dan bernegara untuk mencapai tujuan nasional.

2) Pengertian wawasan Nusantara menurut Prof. DR. Wan Usman (Ketua Program S-2 PKNUI) : "Wawasan Nusantara adalah cara pandang bangsa Indonesia mengenai diri dan tanah airnya sebagai negara kepulauan dengan semua aspek kehidupan yang beragam". Hal tersebut disampaikannya pada waktu lokakarya Wawasan Nusantara dan Ketahanan Nasional di Lemhannas pada bulan Januari Tahun 2000. ia juga menjelaskan bahwa Wawasan Nusantara merupakan geopoltik Indonesia.

3) Pengertian Wawasan Nusantara menurut Kelompok Kerja Wawasan Nusantara yang diusulkan menjadi Ketetapan MPR dan dibuat di Lemhannas tahun 1999 adalah sebagai berikut : "Cara pandang dan sikap bangsa Indonesia mengenai diri dan lingkungannya yang serba beragam dan bernilai strategis dengan mengutamakan persatuan dan kesatuan wilayah dalam menyelenggarakan kehidupan bermasyarakat, berbangsa dan bernegara untuk mencapai tujuan nasional."

\section{Pembahasan}

- Wawasan Nusantara (Wanus) sebagai Konsep Persatuan Bangsa

A. Perwujudan Wanus sebagai Satu Kesatuan Politik

1) Kebulatan wilayah dengan segala isinya merupakan model dan milik bersama bangsa Indonesia

2) Keanekaragaman suku, budaya dan bahasa daerah serta agama yang dianutnya tetap dalam kesatuan bangsa Indonesia.

3) Secara psikologis, bangsa Indonesia merasa satu persaudaraan, senasib, dan seperjuangan, sebangsa dan setanah air untuk mencapai satu cita-cita bangsa yang sama.

4) Pancasila merupakan falsafah dan ideologi pemersatu bangsa Indonesia yang membimbing ke arah tujuan dan cita-cita yang sama.

5) Kehidupan politik di seluruh wilayah nisantara sistem hukum nasional

6) Seluruh kepulauan nusantara merupakan satu kesatuan sistem hukum nasional. 
7) Bangsa Indonesia bersama bangsa-bangsa lain ikut menciptakan ketertiban dunia dan perdamaian abadi melalui politik luar negeri yang bebas dan aktif.

\section{B. Perwujudan Wanus sebagai Satu Kesatuan Ekonomi}

1) Kekayaan di wilayah Nusantara, baik potensial maupun efektif, adalah modal dan milik bersama bangsa untuk memenuhi kebutuhan di seluruh wilayah Indonesia secara merata.

2) Tingkat perkembangan ekonomi harus seimbang dan serasi di seluruh daerah tanpa mengabaikan ciri khas yang memiliki daerah masing-masing.

3) Kehidupan perekonomian di seluruh wilayah Nusantara diselenggarakan sebagai usaha bersama dengan asas kekeluargaan dalam sistem ekonomi kerakyatan untuk sebesar-besar kemakmuran rakyat.

\section{Perwujudan Wanus sebagai Satu Kesatuan Sosial Budaya}

1) Masyarakat Indonesia adalah satu bangsa yang harus memiliki kehidupan serasi dengan tingkat kemajuan yang merata dan seimbang sesuai dengan kemajuan bangsa.

2) Budaya Indonesia pada hakikatnya adalah satu kesatuan dengan corak ragam budaya yang menggembarkan kekayaan budaya bangsa. Budaya Indonesia tidak menolak nilai-nilai budaya asing asalkan tidak bertentangan dengan nilai budaya bangsa sendiri dan hasilnya dapat dinikmati.

D. Perwujudan Wanus sebagai Satu Kesatuan Pertahanan Keamanan

1) Bahwa ancaman terhadap satu pulau atau satu daerah pada hakikatnya adalah ancaman terhadap seluruh bangsa dan negara.

2) Tiap-tiap warga negara mempunyai hak dan kewajiban yang sama untuk ikut serta dalam pertahanan dan keamanan negara dalam rangka pembelaan negara dan bangsa.

\section{E. Wanus sebagai Penjabaran Pancasila}

Falsafah Pancasila diyakini sebagai pandangan hidup bangsa Indonesia yang sesuai dengan aspirasinya. Keyakinan ini dibuktikan dalam sejarah perjuangan bangsa Indonesia sejak awal proses pembentukan negara kesatuan Republik Indonesia sampai sekarang. Konsep Wawasan Nusantara berpangkal pada dasar Ketuhanan Yang Maha Esa sebagai sila pertama yang kemudian melahirkan hakikat misi manusia Indonesia yang terjabarkan pada sila-sila berikutnya. Wawasan Nusantara sebagai aktualisasi falsafah Pancasila menjadi landasan dan pedoman bagi pengelolaan kelangsungan hidup bangsa Indonesia.Dengan demikian Wawasan 
Nusantara menjadi pedoman bagi upaya mewujudkan kesatuan aspek kehidupan nasional untuk menjamin kesatuan, persatuan, dan keutuhan bangsa, serta upaya untuk mewujudkan ketertiban dan perdamaian dunia. Di samping itu Wawasan Nusantara merupakan konsep dasar bagi kebijakan dan strategi Pembangunan Nasional.

\section{F. Wanus sebagai Wawasan Nasional}

1) Sebagai bangsa majemuk yang telah menegara, bangsa Indonesia dalam membina dan membangun atau menyelenggarakan kehidupan nasionalnya, baik pada aspek politik, ekonomi, sosial budaya maupun hankamnya, selalu mengutamakan Bangsa Indonesia bersama bangsa-bangsa lain ikut menciptakan ketertiban dunia dan perdamaian abadi melalui politik luar negeri yang bebas dan aktif.

\section{G. Perwujudan Wanus sebagai Satu Kesatuan Ekonomi}

1) Kekayaan di wilayah Nusantara, baik potensial maupun efektif, adalah modal dan milik bersama bangsa untuk memenuhi kebutuhan di seluruh wilayah Indonesia secara merata.

2) Tingkat perkembangan ekonomi harus seimbang dan serasi di seluruh daerah tanpa mengabaikan ciri khas yang memiliki daerah masing-masing.

3) Kehidupan perekonomian di seluruh wilayah Nusantara diselenggarakan sebagai usaha bersama dengan asas kekeluargaan dalam sistem ekonomi kerakyatan untuk sebesar-besar kemakmuran rakyat.

\section{H. Perwujudan Wanus sebagai Satu Kesatuan Sosial Budaya}

1) Masyarakat Indonesia adalah satu bangsa yang harus memiliki kehidupan serasi dengan tingkat kemajuan yang merata dan seimbang sesuai dengan kemajuan bangsa.

2) Budaya Indonesia pada hakikatnya adalah satu kesatuan dengan corak ragam budaya yang menggembarkan kekayaan budaya bangsa. Budaya Indonesia tidak menolak nilai-nilai budaya asing asalkan tidak bertentangan dengan nilai budaya bangsa sendiri dan hasilnya dapat dinikmati.

\section{Perwujudan Wanus sebagai Satu Kesatuan Pertahanan Keamanan}

1) Bahwa ancaman terhadap satu pulau atau satu daerah pada hakikatnya adalah ancaman terhadap seluruh bangsa dan negara.

2) Tiap-tiap warga negara mempunyai hak dan kewajiban yang sama untuk ikut serta dalam pertahanan dan keamanan negara dalam rangka pembelaan negara dan bangsa. 


\section{J. Wanus sebagai Penjabaran Pancasila}

Falsafah Pancasila diyakini sebagai pandangan hidup bangsa Indonesia yang sesuai dengan aspirasinya. Keyakinan ini dibuktikan dalam sejarah perjuangan bangsa Indonesia sejak awal proses pembentukan negara kesatuan Republik Indonesia sampai sekarang. Konsep Wawasan Nusantara berpangkal pada dasar Ketuhanan Yang Maha Esa sebagai sila pertama yang kemudian melahirkan hakikat misi manusia Indonesia yang terjabarkan pada sila-sila berikutnya. Wawasan Nusantara sebagai aktualisasi falsafah Pancasila menjadi landasan dan pedoman bagi pengelolaan kelangsungan hidup bangsa Indonesia. Dengan demikian Wawasan Nusantara menjadi pedoman bagi upaya mewujudkan kesatuan aspek kehidupan nasional untuk menjamin kesatuan, persatuan, dan keutuhan bangsa, serta upaya untuk mewujudkan ketertiban dan perdamaian dunia. Di samping itu Wawasan Nusantara merupakan konsep dasar bagi kebijakan dan strategi Pembangunan Nasional.

\section{K. Wanus sebagai Wawasan Nasional}

Sebagai bangsa majemuk yang telah menegara, bangsa Indonesia dalam membina dan membangun atau menyelenggarakan kehidupan nasionalnya, baik pada aspek politik, ekonomi, sosial budaya maupun hankamnya, selalu mengutamakan persatuan dan kesatuan bangsa serta kesatuan wilayah. Untuk itu pembinaan dan penyelenggaraan tata kehidupan bangsa dan negara Indonesia disusun atas dasar hubungan timbal balik antara falsafah, cita-cita dan tujuan nasional, serta kondisi sosial budaya dan pengalaman sejarah yang menumbuhkan kesadaran tentang kemajemukan dan kebhinnekaannya dengan mengutamakan persatuan dan kesatuan nasional. Gagasan untuk menjamin persatuan dan kesatuan dalam kebhinnekaan tersebut merupakan cara pandang bangsa Indonesia tentang diri dan lingkungannya,yang dikenal dengan istilah Wawasan Kebangsaan atau Wawasan Nasional Indonesia dan diberi nama Wawasan Nusantara, disingkat "Wasantara"

\section{- Ajaran Dasar Wawasan Nusantara}

1. Landasan Idiil Pancasila Pancasila diakui sebagai ideology dan dasar Negara yang dirumuskan dalam pembukaan UUD 1945. Yang telah mencerminkan nilai-nilai keseimbangan, keserasian, keselarasan, persatuan dan kesatuan, kekeluargaa, kebersamaan dan kearifan dalam membina kehidupan nasional. 
2. Landasan Konstitusional : UUD 1945 UUD 1945 merupakan konstitusi dasar yang menjadi pedoman pokok dalam kehidupan masyarakat, berbangsa dan bernegara.

- Dasar Hukum Wawasan Nusantara

Dasar hukum wawasan nusantara diterima sebagai konsepsi politik kewarganegaraan yang tercantum dalam dasar-dasar hukum antara lain sebagai berikut :

- Tap MPR. No. IV/MPR/1973 pada tanggal 22 maret 1973.

- Tap MPR. No IV/1978/22/Maret/1978/ tentang GBHN.

- Tap MPR. No. II/MPR/1983/12/Maret/1983

- Tujuan Wawasan Nusantara

Wawasan nusantara bertujuan mewujudkan nasionalisme yang tinggi di segala aspek kehidupan rakyat Indonesia yang lebih mengutamakan kepentingan nasional daripada kepentingan individu, kelompok, golongan, suku bangsa ataupun daerah. Hal tersebut bukan berarti menghilangkan kepentingankepentingan individu, kelompok, suku bangsa, ataupun daerah. Kepentingankepentingan tersebut tetap dihormati, diakui dan dipenuhi selama tidak bertentangan dengan kepentingan nasional atau kepentingan masyarakat banyak.

\section{E. Kesimpulan}

Wawasan Nusantara adalah cara pandang suatu bangsa tentang diri dan lingkungannya yang dijabarkan dari dasar falsafah dan sejarah bangsa itu sesuai dengan posisi dan kondisi geografi negaranya untuk mencapai tujuan atau cita-cita nasionalnya. Dalam penerapan Wawasan Nusantara harus tercermin pada pola dan tindak yang senantiasa mendahulukan kepentingan bangsa dan negara dari pada kepentingan pribadi atau kelompok. Dengan kata lain, Wawasan Nusantara menjadi pola yang mendasari cara berpikir, bersikap dan bertindak dalam rangka menghadapi berbagai masalah yang menyangkut kehidupan berbangsa dan bernegara. Penerapan Wawasan Nusantara selalu berorientasi pada kepentingan rakyat dan wilayah tanah air secara utuh dan menyeluruh. 


\section{F. Daftar Pustaka}

Ilyasa, A. (2021, June). Wawasan Nusantara. In UNUSIA CONFERENCE (Vol. 1, No. 1, pp. 227-238).

Aminullah, R., \& Umam, M. (2020). Pancasila sebagai Wawasan Nusantara.

Kusrahmadi, S. D. (2017). Pentingnya Wawasan Nusantara dan Integrasi Nasional.

Sodik, M. A., Salam, D. M., \& Kardjati, S. (2020). Analysis Of Android-Based Online Message Gateway Towards The Use Of Plastic Bags. STRADA Jurnal Ilmiah Kesehatan, 9(2), 16571664.

NABILA, W. S. (2021). Dampak Pemilihan Umum Serentak Bagi Pembangunan Demokrasi Indonesia. 